\title{
Effect of Citrus aurantium L. Essential Oil on Muscle Regeneration in Mdx Mice
}

\author{
Efecto del Aceite Esencial de Citrus aurantium L. en la Regeneración Muscular en Ratones Mdx
}

"Paula Aiello Tomé De Souza; *** Maria Júlia Marques; ${ }^{* * *}$ Clélia Akiko Hiruma Lima \& **Selma Maria Michelin Matheus

DE SOUZA, P. A. T.; MARQUES, M. J.; LIMA, C. A. H. \& MATHEUS, S. M. M. Effect of Citrus aurantium 1. essential oil on muscle regeneration in mdx mice. Int. J. Morphol., 29(4):1357-1363, 2011.

SUMMARY: Duchenne muscular dystrophy (DMD) is a severe X-linked recessive disorder characterized by the progressive loss of muscular strength. Mdx mutant mice show a marked deficiency in dystrophin, which was related to muscle membrane stability. The aim of this study was to verify the possible protective anti-inflammatory effect of citrus oil on mdx muscle fibers. Thus, adult male and female mdx mice (014/06-CEEA) were divided into control and citrus-treated. After 60 days of treatment, one ml of blood was collected for creatine kinase (CK) test. Diaphragm, sternomastoideus, anterior tibial and gastrocnemius muscles were removed and processed according to histological routine methods. The observed alterations indicate a direct effect of citrus. Recent studies have improved the diagnosis of muscular diseases but with no definitions of efficient treatments. Intervention with several therapies is important to many patients presenting muscular dystrophy, which enables them to live longer and be more active, while there is no development of gene therapies.

KEY WORDS: Muscle fiber; Duchenne muscular dystrophy; Citrus aurantium L.; mdx mouse, Muscle regeneration; Central nuclei; Creatine kinase.

\section{INTRODUCTION}

Muscular dystrophies are genetically determined primary progressive myopathies (Robbins et al., 1989; Engel, 2003). Duchenne type is the most frequent and severe form of dystrophy since it is progressive, lethal and affects male children (Tidball \&Wehling-Henricks, 2004). The child presents delayed motor development, frequent falls, difficulties to run, and increased muscular volume or calf pseudohypertrophy. Frequently, by 12 years old, the child cannot walk and is only able to move fingers, tongue and respiratory muscles (Engel et al.).

Duchenne muscular dystrophy (DMD) is an X-linked myopathy caused by a mutation in the dystrophin gene (Takeda, 2001). Dystrophin is a protein present on the cytoplasmic surface of sarcolemma. The complex dystrophinglycoproteins, expressed at high concentrations in the striated muscle, connects the muscle fiber cytoskeleton (actin) to the extracellular matrix and is composed of sarcolemmal proteins (Campbell \& Kahl, 1989, Ervasti \& Campbell,
1991). Linked to integrating proteins, dystrophin stabilizes and prevents failures in the sarcolemma during cycles of muscle contraction-relaxation, keeping the muscle fiber integrity (Engel et al.; Gramolini \& Jasmin, 1998).

Mdx mutants are the preferred animal models for DMD studies (Torres \& Duchen, 1987). In mice, muscular degeneration begins around the third week of age and persists until nearly one month, with muscle loss compensated by regeneration cycles (Marques et al., 2004). Despite the differences between mdx and human phenotypes, experiments in mdx mice have provided incalculable information about DMD pathogenesis (Marques et al.).

Serum enzymes such as creatine kinase $(\mathrm{CK})$, creatine kinase MB (CK-MB), aldolase (ALD), and lactate dehydrogenase (LDH) present increased activity under DMD conditions during the first three years of life, which indicates muscular degeneration (Pernice et al., 1988). The activity

\footnotetext{
* Department of Morphology, Institute of Biosciences, São Paulo State University (UNESP), Botucatu Municipality, São Paulo State, Brazil. ** Department of Anatomy, Institute of Biology, State University of Campinas (UNICAMP), Campinas Municipality, São Paulo State, Brazil. **** Department of Physiology, Institute of Biosciences, São Paulo State University (UNESP), Botucatu Municipality, São Paulo State, Brazil. Grant Fundunesp proc. nº 01268/11-DFP.
} 
of these muscle enzymes is important for the diagnosis of muscular diseases. CK is more marked at the initial stages of the disease and its activity decreases together with the muscular activity (Engel et al.).

As a new therapeutic resource, phytotherapy has become increasingly popular among people in the whole world. Popularly known as sour orange (Santos et al., 1988; Sanguinetti, 1989; Vieira, 1992), Citrus aurantium L. (Rutaceae) originated from Southeast Asia, India and China. This species is used to treat disorders of the gastrointestinal tract (Carvalho-Freitas \& Costa, 2002; Pultrini et al., 2006). Citrus fruits are rich in flavonoids, which have been considered modifiers of the biological response; most of the latter act as antioxidants, and some have notable anti-inflammatory properties (Theoharides $e t$ al., 2001).

Thus, the aim of the present work was to identify a possible anti-inflammatory action of Citrus aurantium L. in order to minimize the effects of muscle fiber degeneration in $\mathrm{mdx}$ mice.

\section{MATERIAL AND METHOD}

Essential oil. A plant sample of the specie $C$. aurantium was collected and the exsiccates deposited in the Herbarium "Irina D. Gemtchujnicov"-BOTU, Department of Botany at Unesp, under $n^{\circ}$ BOTU 23123. After the fruits were collected at Unesp-Botucatu, fresh fruit peels of $C$. aurantium L. were submitted to extraction of essential oil by water vapor with the aid of a Clevenger type device (Marconi, Brazil). The vegetal material (fruits peels) was mixed inside a glass balloon $(5 \mathrm{~L})$ with distilled water and put on a heated pad. The essential oil (OEC) obtained was stored in an amber bottle at $5^{\circ} \mathrm{C}$ temperature until the accomplishment of the pharmacological experiments and phytochemical analyses (Moraes et al., 2009).

Animals. Ten mice of both sexes, strain C57BL/10, were used. After weaning, these animals were brought from the animal facility of the Department of Anatomy, Institute of Biology, State University of Campinas (UNICAMP), Campinas Municipality, São Paulo State, Brazil, to the animal facility of the Department of Immunology, Institute of Biosciences, São Paulo State University (UNESP), Botucatu Municipality, São Paulo State, Brazil, where they were kept in individual cages with water and food $a d$ libitum. The animals were divided into one control $(\mathrm{n}=5)$ and one treated group $(n=5)$. The latter received essential oil of citrus $(50 \mathrm{mg} / \mathrm{kg}$ ) diluted in Tween $8 \%$ through gavage for 60 days. The essential oil was provided and elaborated by the Laboratory of Natural Products of the Department of Physiology, Institute of Biosciences, UNESP Botucatu, Brazil.

During the same 60 days, the control group received distilled water through gavage. The animals were kept in individual cages, under suitable environmental conditions (12h dark/light), with food and water ad libitum (014/06CEEA).

Anesthesia, sacrifice and muscle collection. After 60 days of treatment, the animals were anesthetized with Hypnol $2 \%$; then, around $1 \mathrm{ml}$ blood was collected by intracardiac puncture and frozen until CK test. Afterward, animals were euthanized by receiving an excessive anesthetic dose and were dissected for the removal of the following muscles: sternomastoideus, gastrocnemius, anterior tibial and diaphragm, which were fixed in $10 \%$ buffered paraformaldehyde. After around $48 \mathrm{~h}$, this material was washed in tap water and prepared for inclusion in paraplast. Sections of $5 \mu \mathrm{m}$ thickness were obtained and HE-stained.

Analysis procedure. The histological sections $(5 \mu \mathrm{m}$ thickness) of control( $n=5)$ and treated(n=5) muscles were observed under a light microscope (Axioplan 2) with objective of 20X magnification attached to a digital camera (AxioCam HR) to capture the image linked to the computer Pentium ${ }^{\circledR}$ 4.0. The number of fibers presenting central nucleus was evaluated since it indicates the regenerated muscle fibers (Torres \& Duchen). The number of normal and regenerated fibers was obtained by using the software AxioVision 4.0.

Creatine kinase test. After collection, the blood was centrifuged and subjected to the biochemical assay of creatine kinase according to the kinetic method (Moura, 1982), in which the speed of creatine formation from creatine phosphate was recorded. Spectrophotometric absorbance readings were done by using a microplate reader ( $\mu$ Quant, BioTek Instruments, Inc.) at $340 \mathrm{~nm}$ and were recorded after 1-, 2- and 3-min intervals. The speed of creatine release was proportional to the creatine kinase activity in the sample.

Statistical analysis. Results were expressed as Standard Deviation and statistical significance the T-test was used to compare means between control and treated animals test with $\mathrm{P}<0.05$ defined as significant. As regards central nucleus count, a logarithmic transformation was done for all variables (number of central nuclei in different muscle groups). 


\section{RESULTS}

The fibers of the studied muscles had oval, round or polygonal shape and different diameters. Each muscle fiber is involved by a loose connective tissue named endomysium. The grouping of several fibers form muscle fascicles that are delimited by a relatively dense connective tissue named perimysium.

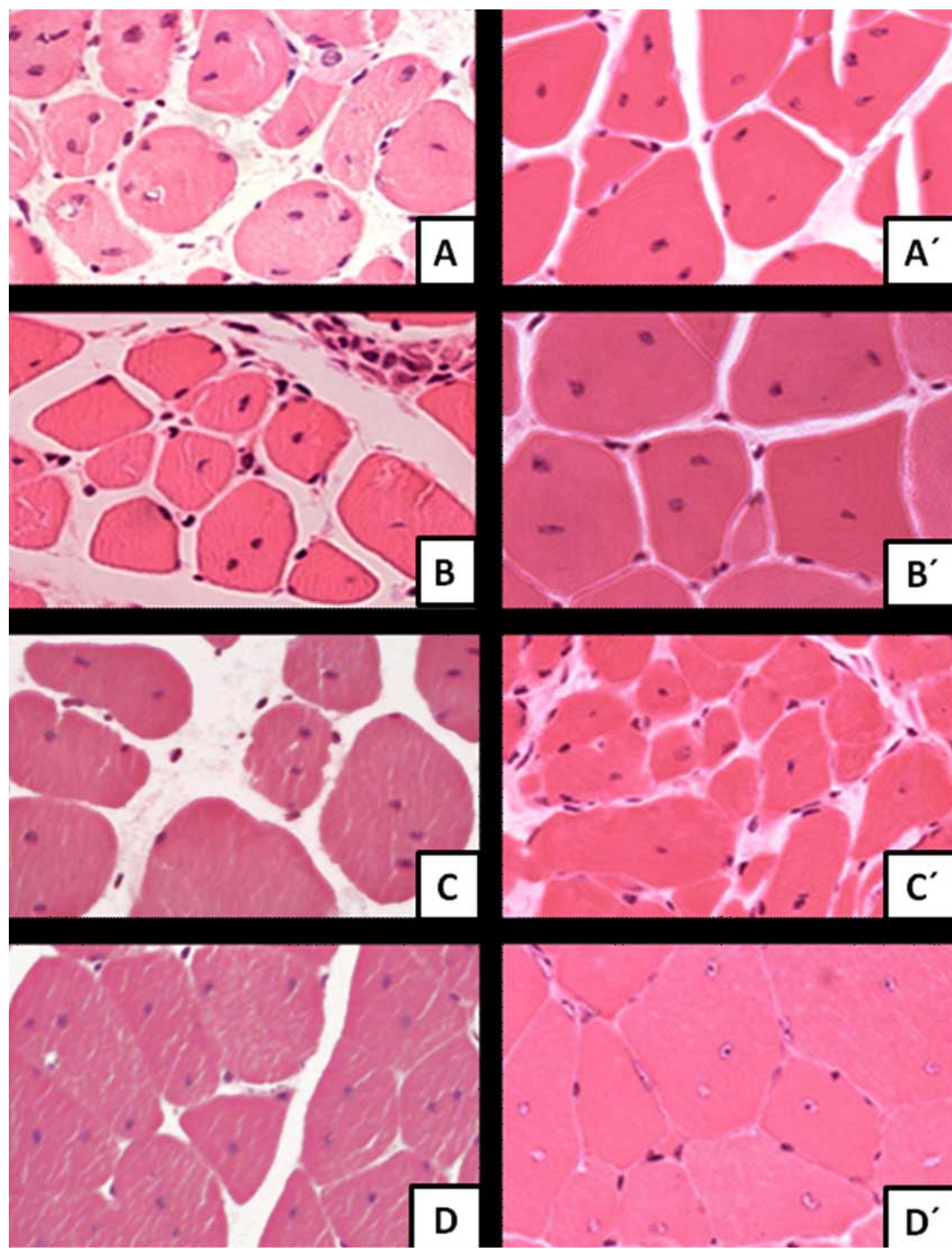

Fig. 1. Photomicrography of fibers muscular dystrophy with central nuclei in mdx mice. Transversal sections of the studied muscles. (A): Anterior Tibial - control, (A'): Anterior Tibial - treated, (B): Sternomastoideus - control, (B'): Sternomastoideus - treated, (C): Diaphragm - control, (C'): Diaphragm - treated, (D): Gastrocnemius - control, (D'): Gastrocnemius - treated.
Histological evaluations did not indicate any morphological differences between muscles from control (Fig. 1 A', B', $\left.\mathrm{C}^{\prime}, \mathrm{D}^{\prime}\right)$ and those from treated animals (Fig. 1A, B, C, D). Thus, there were fibers with peripheral nucleus, degenerating fibers, and fibers at different regeneration stages in both groups. Fibers with peripheral nucleus had polygonal shape and were juxtaposed to other fibers with the same characteristic. Regenerated fibers had centralized and condensed nucleus; some fibers had up to two central nuclei and eosinophilic cytoplasm, and their diameter was similar to that of muscle fibers with peripheral nucleus. On the other hand, degenerating fibers presented irregular contours, were weakly HE-stained and apparently fragmented.

The number of central nuclei, which is used to verify muscle regeneration, indicated that the fibers underwent regeneration, since central nuclei were observed in all studied muscles from the treated group; some fibers had up to two central nuclei.

The muscles AT and GASTR had a larger number of central nuclei, as shown in Figure 1. Significant 
differences could not be verified for this variable. Thus, Citrus aurantium L. can be assumed not to impair the muscle regeneration process.

The anterior tibial muscles, diaphragm and gastrocnemius showed larger number of central nuclei compared to control values as plotted in the figure 2 , which indicates no significant difference between groups. P-value $<0.05$ was adopted for the t-test.
The CK test according to the kinetic method showed that the treated group had high levels of this enzyme, with acute anti-inflammatory effect. In this case, Citrus aurantium L. did not have the expected action, as shown in Figure 3.

The CK test according to the kinetic method showed that the treated group had high levels of this enzyme, with acute anti-inflammatory effect. In this case, Citrus aurantium L. did not have the expected action, as shown in Figure 3.

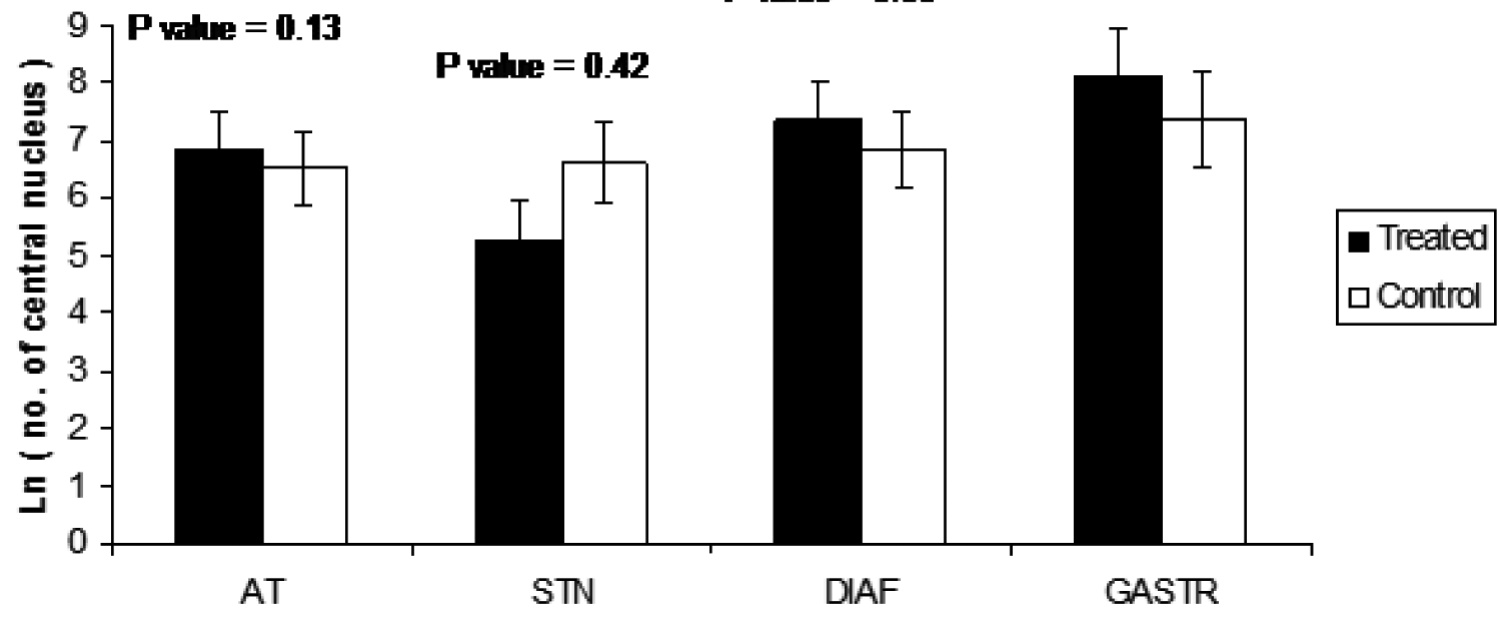

Fig. 2. Logarithmic transformation for all variables (number of central nuclei in different muscle groups) to compare means between control and treated animals according to the t-test.

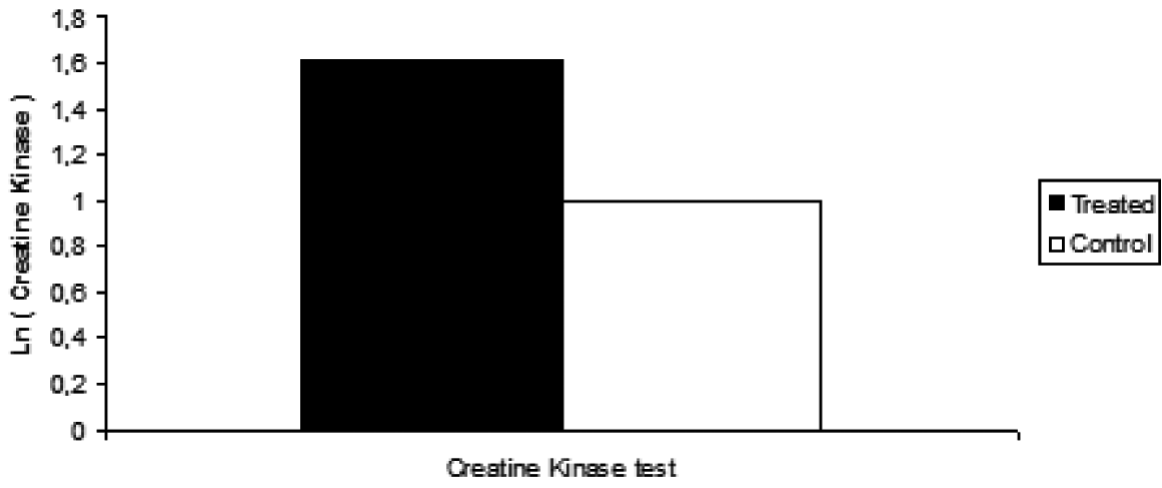

Fig. 3. Creatine kinase (CK) test according to the kinetic method to evaluate CK activity after treatment with citrus. 


\section{DISCUSSION}

In the treatment of DMD, the pharmacological strategies are mainly aimed at decreasing the muscle involvement, minimizing the functional damages due to the disease (Porter et al., 2004). Anti-inflammatory corticosteroids have been widely used as an attempt to reduce the disease progress; however, their side effects are severe (Muntoni et al., 2002, Parreira et al., 2007, Radley et al., 2007, Manzur et al., 2004). Alternative pharmacological strategies such as the use of nonsteroidal anti-inflammatory drugs (NSAIDs) have become an option, since these drugs cause less severe side effects. In addition, medicinal plants can be also used by means of phytotherapy. According to the Board of Directors resolution n.48/2004 from the National Health Surveillance Agency - ANVISA, herbal medicines are exclusively elaborated with medicinal plants or part of them (roots, barks, leaves, fruits or seeds), which have properties for healing, prevention, diagnosis or symptomatic treatment of diseases (Arnous et al., 2005). The use of plants to treat and heal diseases is as old as humankind and has great importance nowadays in the attempt to join folk and scientific knowledge. Known as sour orange, Citrus aurantium L. has been used by the folk medicine in Brazil and other countries to treat anxiety, hysteria, depression and insomnia; it also presents other important properties. Its chemical constituents include some flavonoids that show anti-cancer and anti-inflammatory actions (Manthey et al., 2001).

Under pathological conditions, such as myopathies and dystrophies, an excessive inflammatory response can lead to myonecrosis in addition to the lesion caused by an excess of the ion calcium inside muscle fibers. The inhibition of inflammatory cells can reduce muscle tissue degeneration and necrosis. Studies with anti-inflammatory drugs showed a significant reduction in myonecrosis in skeletal muscles from mdx mice (Tidball \& Wehling-Henricks; Marques et $a l$.). Myonecrosis was not observed in the present study; however, several degenerating regions and oval-shaped atrophied fibers were detected, which characterizes this pathology.

In some studies, muscle regeneration was impaired due to the use of NSAIDs (Huard, 2003), whereas in other works muscle regeneration occurred normally (Järvinen $e t$ al., 2005).

In the present study, there was no significant difference in the central nucleus count between the control and the treated group. A tendency toward an increase in central nuclei was observed for anterior tibial and gastrocnemius muscles. Thus, the beneficial effect of Citrus aurantium $\mathrm{L}$. as anti-inflammatory cannot be ruled out. Albuquerque (2008) reported that the anti-inflammatory drugs naproxen and nimesulide had different actions in the studied muscle groups. After treatment with naproxen, anterior tibial and sternomastoideus muscles presented a different behavior relative to that of the saline-treated control group; furthermore, central and peripheral nuclei decreased in the anterior tibial muscle. On the other hand, nimesulide did not significantly change the proportions of central and peripheral nuclei from anterior tibial and sternomastoideus muscles.

Citrus has been proven to present anti-inflammatory action against ulcer by inhibiting $\mathrm{H}+$ release and leading to increased gastric mucus secretion (Moraes et al., 2007; 2009). Nevertheless, components isolated from citrus still must be tested before their anti-inflammatory action on the striated muscle is ruled out.

Expectations of treatments for DMD remain uncertain; however, several studies involving gene therapy (De Luca et al., 2008) and pharmacological treatments (Pierno et al., 2007) have been published in the attempt to find solutions for this type of dystrophy (Yoshida et al., 2006). The disease evolves with progressive muscle loss, replacement of muscle fibers for fibroadipose tissue and increased interstitial connective tissue (Seixas et al., 1997).

In mdx mice, up to three months old, there is an increase in the number of fibers with central nucleus undergoing degeneration-regeneration cycles, whereas spontaneous regeneration is followed by muscle fiber necrosis (Torres \& Duchen). The diaphragm and smooth muscles have different time of response to the dystrophin deficiency (Porter et al.). Anterior tibial muscle degenerates between 3 and 4 weeks after birth and presents disorganized cytoskeleton and sarcolemma at 18 days postnatal, tending to increase over time. It has few central nuclei at 18 days and increased myofibril diameter in one month (Reed \& Bloch, 2005).

As regards CK test, the high level of this enzyme may be due to factors of the studied microenvironment, where the activity of enzymes such as CK is lower, associated with increased production of inflammatory cytokines (Maegaki et al., 1999). Tissue repair cycles are monitored by a sequence of biochemical and cell events organized to restore the tissue integrity after the lesion. There is participation of the immune system acting in the protection of injured tissues against possible infections and in the secretion of growth factors such as cytokines, which metabolically change the morphological state of animal 
tissues (Park \& Barbul, 2004; Gawronska-Kozak et al., 2006). Oral supplementation of $\mathrm{NaCl}$ decreases $\mathrm{CK}$ activity, but whether the inhibition of mdx muscle degeneration occurs before fiber necrosis remains unknown. Mdx mice treated with saline doses present a difference in CK activity between males and females during the days of treatment. In the control group, the animals treated with naproxen and nimesulide for 15 days had higher plasmatic levels (Albuquerque). The diagnosis and progress of neuromuscular diseases should not be based solely on CK values, which must be used as complementary data for the disease diagno- sis. In DMD carriers, these values may be 50 to 100 fold higher than the minimum reference value (Engel et al.). In mdx mice, CK serum levels are high during their whole life due to the successive muscle degeneration-regeneration cycles (Yoshida et al.).

Studies related to factors that promote and act on the inflammatory process typical of this dystrophy will probably enable the identification and elucidation of some still obscure aspects of this pathology.

DE SOUZA, P. A. T.; MARQUES, M. J.; LIMA, C. A. H. \& MATHEUS, S. M. M. Efecto del aceite esencial de Citrus aurantium 1. en la regeneración muscular en ratones mdx. Int. J. Morphol., 29(4):1357-1363, 2011.

RESUMEN: La distrofia muscular de Duchenne (DMD) es una enfermedad grave ligada al cromosoma X, trastorno recesivo que se caracteriza por la pérdida progresiva de fuerza muscular. Mdx ratones mutantes muestran una marcada deficiencia en la distrofina, que está relacionada con la estabilidad de la membrana muscular. El objetivo de este estudio fue comprobar el posible efecto protector, antiinflamatorio del aceite de cítricos en las fibras musculares mdx. Los ratones mdx adultos machos y hembras (014/06-CEEA) se dividieron en control y cítricos tratados. Después de 60 días de tratamiento, un ml de sangre fue recogida para cuantificar la creatina quinasa (CK) de prueba. Fueron retirados y procesados los músculos diafragma, esternomastoideo, tibial anterior y gastrocnemio de acuerdo con los métodos de rutina histológica. Las alteraciones observadas indican un efecto directo de los cítricos. Estudios recientes han mejorado el diagnóstico de enfermedades musculares, pero sin definiciones de tratamientos eficaces. Intervención con varias terapias es importante para muchos pacientes que presentan distrofia muscular, lo que les permite vivir más y ser más activos, mientras no exista desarrollo de terapias génicas.

PALABRAS CLAVE: Fibra muscular; Distofia muscular Duchenne; Citrus aurantium L.; Ratón mdx; Regeneración muscular; Núcleo central; Creatina kinasa.

\section{REFERENCES}

Albuquerque, T. C. P. Nonsteroidal antiinflamatory influence in the degeneration/regeneration cycles of mdx mice dystrophic muscle fibers. Master's Dissertation. Institute of Biology, State University of Campinas, Campinas, SP, 2008.

Arnous, A. H.; Santos, A. S. \& Beinner, R. P. C. Plantas medicinais de uso caseiro-conhecimento popular e interesse por cultivo comunitário. Revista Espaço para a Saúde, 6(2):1-6, 2005.

Campbell, K. P. \& Kahl, S. D. Association of dystrophin and an integral membrane glycoprotein. Nature, 338:259-62, 1989.

Carvalho-Freitas, M. I. \& Costa, M. Anxiolytic and sedative effects of extracts and essential oil from Citrus aurantium L. Biol. Pharm. Bull., 25(12):1629-33, 2002.

De Luca, A.; Nico, B.; Rolland, J. F.; Cozzoli, A.; Burdi, R.; Mangieri, D.; Giannuzzi, V.; Liantonio, A.; Cippone, V.; De Bellis, M.; Nicchia, G. P.; Camerino, G. M.; Frigeri, A.; Svelto, M. \& Camerino, D. C. Gentamicin treatment in exercised mdx mice: Identification of dystrophin-sensitive pathways and evaluation of efficacy in work-loaded dystrophic muscle. Neurobiol. Dis., 2:243-53, 2008.
Engel, A. G.; The neuromuscular junction. In: Engel, A. G. \& Frazini-Armstrong, C. Myology: Basic and Clinical. $3^{\text {a }}$ ed. New York. Edition International, USA, McGraw-Hill, 2003. p. p. 325-72, V. 1.

Ervasti, J. M. \& Campbell, K. P. Membrane organization of the dystrophin-glicoprotein complex. Cell, 66(6):1121-31, 1991.

Gawronska-Kozak, B.; Bogacki, M.; Rim, J. S.; Monroe, W. T. \& Manuel, J. A. Scarless skin repair in immunodeficient mice. Wound Repair Regen., 14(3):265-76, 2006.

Gramolini, A. O. \& Jasmin, B. J. Molecular mechanisms and putative signalling events controlling utrophin expression in mammalian skeletal muscle fibres. Neuromuscul. Disord., 8(6):351-61, 1998.

Huard, J.; Li, Y. \& Fu, F. H. Muscle Injuries and Repair: Current Trends in Research. J. Bone Joint Surg. Am., 84:822-32, 2002.

Järvinen, T. A.; Järvinen, T. L.; Kääriäinen, M.; Kalimo, H. \& Järvinen, M. Muscle injuries: biology and treatment. Am. J. Sports Med., 33(5):745-64, 2005.

Maegaki, Y.; Ogura, K.; Maeoka, Y. \& Takeshita, K. Normalization of creatine kinase level during arthritis in a patient with Becker muscular dystrophy. Neurology, 52(1):172-4, 1999. 
Manthey, J. A.; Grohmann, K. \& Guthrie, N. Biological properties of citrus flavonoids pertaining to cancer and inflammation. Curr. Med. Chem., 8(2):135-53, 2001.

Manzur, A. Y.; Kuntzer, T.; Pike, M. \& Swan, A. Glucocorticoid corticosteroids for Duchenne muscular dystrophy. Cochrane Database Syst. Rev., (2):CD003725, 2004.

Marques, M. J. Structural biology of the dystrophin-deficient muscle fiber. Braz. J. Morphol. Sci., 21(3):145-52, 2004.

Moraes, T. M.; Rozza, A. L.; Peliizzon, C. H. \& Lima, C. A. H. Mechanisms and antiulcer activity of essencial il of Citrus aurantium and its isolated compounds. In: 39 Brazilian Congress of Pharmacology and Experimental Therapeutics, Ribeirão Preto - SP, 2007.

Moraes, T. M.; Kushima, H.; Moleiro, F. C.; Santos, R. C.; Rocha, L. R. M.; Marques, M. O.; Vilegas, W. \& Hiruma-Lima, C. A. Effects of limonene and essential oil from Citrus aurantium on gastric mucosa: role of prostaglandins and gastric mucus secretion. Chem. Biol. Interact., 180:499-505, 2009.

Moura, R. A. Tecnics of laboratory. São Paulo, Editors Atheneu, 1982, p. 822.

Muntoni, F.; Fisher, I.; Morgan, J. E. \& Abraham, D. Steroids in Duchenne muscular dystrophy: from clinical trials to genomic research. Neuromuscul. Disord., 12:S162-5, 2002.

Park, J. E. \& Barbul, A. Understanding the role of immune regulation in wound healing. Am. J. Surg., 187(5A):11S-16S, 2004.

Parreira, S. L.; Resende, M. B.; Della Corte Peduto, M.; Marie, S. K.; Carvalho, M. S. \& Reed, U. C. Quantification of muscle strength and motor ability in patients with Duchenne muscular dystrophy on steroid therapy. Arq. Neuropsiquiatr. 65(2A):245-50, 2007.

Pernice, W.; Beckmann, R.; Ketelsen, U. P.; Frey, M.; SchmidtRedemann, B.; Haap, K. P.; Roehren, R. \& Sauer, M. A doubleblind placebo controlled trial of diltiazem in Duchenne dystrophy. Klin. Wochenschr., 66(13):565-70, 1988.

Pierno, S.; Nico, B.; Burdi, R.; Liantonio, A.; Didonna, M. P.; Cippone, V.; Fraysse, B.; Rolland, J. F.; Mangieri, D.; Andreetta, F.; Ferro, P.; Camerino, C.; Zallone, A.; Confalonieri, P. \& De Luca, A. Role of tumour necrosis factor alpha, but not of cyclo-oxygenase-2-derived eicosanoids, on functional and morphological indices of dystrophic progression in mdx mice: a pharmacological approach. Neuropathol. Appl. Neurobiol., 3(33):344-59, 2007.

Porter, J. D.; Meriam, A. P.; Leavy, P.; Gong, B.; Feuerman, J.; Cheng, G. \& Khanna, S. Temporal gene expression profiling of dystrophin-deficient (mdx) mouse diaphragm identifies conserved and muscle group- specific mechanisms in the pathogenesis of muscular dystrophy. Hum. Mol. Genet., 13(3):257-69, 2004
Pultrini Ade, M.; Galindo, L. A. \& Costa, M. Effects of the essential oil from Citrus aurantium L. in experimental anxiety model in mice. Life Sci., 78(15):1720-5, 2006.

Radley, H. G.; De Luca, A.; Lynch, G. S. \& Grounds, M. D. Duchenne muscular dystrophy: focus on pharmaceutical and nutritional interventions. Int. J. Biochem. Cell Biol., 39 (3):469-77, 2007.

Reed, P. \& Bloch, R. J. Postnatal changes in sarcolemmal organization in the mdx mouse. Neuromuscul. Disord., 15(8):552-61, 2005.

Robbins, S. L.; Kumar, V. \& Cotran, R. S. The musculoskeletal system. In: Pathologic basis of disease. W.B. Saunders International Edition, 1989. pp.1315-84.

Sanguinetti, E. E. Plantas que curam. $2^{\mathrm{a}}$ ed. Porto Alegre, Rígel, 1989. p. 208.

Santos, C. A. M.; Torres, K. R. \& Leonart, R. Plantas medicinais herbarium, flora et scientia. $2^{\mathrm{a}}$ ed. Sao Paulo, Ícone, 1988. p. 160

Seixas, S. L.; Lagrota-Ca ndido, J.; Savino, W. \& Quirico-Santos, T. The importance of $\mathrm{mdx}$ mouse in the physiopathology of Duchenne's muscular dystrophy. Arq. Neuropsiquiatr., 55(3B):610-7, 1997

Takeda, S. Development of new therapy on muscular dystrophy. Rinsho Shinkeigaku, 41(12):1154-6, 2001.

Theorarides, T. C.; Alexandrakis, M.; Kempuraj, D. \& Lytinas, M. Anti-inflammatory actions of flavonoids and structural requirements for new design. Int. J. Immunophatol. Pharmacol., 14(3):119-27, 2001.

Tidball, J. G. \& Wehling-Henricks, M. Evolving therapeutic strategies for Duchenne muscular dystrophy: targeting downstream events. Pediatr. Res., 56(6):831-41, 2004

Torres, L. F. \& Duchen, L. W. The mutant mdx: inherit myopathy in the mouse. Morphological studies of nerves, muscles and endplates. Brain, 110(pt2):269-99, 1987.

Vieira, L. S. Fitoterapia da Amazônia: manual de plantas medicinais. $2^{a}$ ed. Sao Paulo, Agronômica Ceres, 1992.

Yoshida, M.; Yonetani, A.; Shirasaki, T. \& Wada, K. Dietary $\mathrm{NaCl}$ supplementation prevents muscle necrosis in a mouse model of Duchenne muscular dystrophy. Am. J. Physiol. Regul. Integr. Comp. Physiol., 290(2):449-55, 2006.

Correspondence to:

Paula Aiello Tomé de Souza

Laboratório Biologia do Músculo Estriado

Departamento de Morfologia/IBB/UNESP/Botucatu

BRASIL

Email: pats_souza@yahoo.com.br Received: 28-04-2011 Accepted: 04-08-2011 